\title{
Ameliorative Effect of Lycopene on Lipid Peroxidation and Certain Antioxidant Enzymes in Diabetic Patients
}

Kuldip Singh ${ }^{1 *}$, Bal BS ${ }^{2}$, Seema Chopra ${ }^{1}$, Saranpal Singh ${ }^{3}$ and Naresh Malhotra ${ }^{4}$

${ }^{1}$ Department of Biochemistry, Govt. Medical College, Amritsar-143001, India

${ }^{2}$ Department of Medicine, Guru Nanak Dev Hospital, Govt. Medical College, Amritsar, India

${ }^{3}$ Department of Biochemistry, Gian Sagar Medical College, Banur, Punjab, India

${ }^{4}$ Department of Biochemistry, Sri Guru Ramdas Institute Medical Sciences, Amritsar, India

\begin{abstract}
Objectives: To study the ameliorative properties of lycopene in diabetic patients by measuring oxidative stress biomarkers such as malondialdehyde (MDA), antioxidant enzymes like xanthine oxidase (XOD), superoxide dismutase (SOD), glutathione peroxidase (GPx), glutathione reductase (GR) and low molecular weight antioxidant compound that is reduced glutathione (GSH) in diabetic patients.
\end{abstract}

Materials and Methods: The subjects were divided into three groups: Group-1: Normal healthy subjects (Control); Group- 2: Diabetic patients and Group- 3: $4 \mathrm{mg}$ lycopene ingested diabetic patients. The levels of MDA, XOD, SOD, GPx, GR and GSH were determined in blood samples in all the groups for evaluation of oxidantantioxidant status.

Results: A significant $(p<0.001)$ elevation in MDA and XOD levels while a significant $(p<0.01)$ reduction in SOD, GPx, GR and GSH levels was observed in diabetic patients. Oral administration of lycopene (4 mg once daily for 3 months) to diabetic patients attenuated the oxidative stress by significantly $(p<0.01)$ decreasing the levels of MDA and XOD. In addition, lycopene significantly $(p<0.01)$ increased the SOD, GSH, GPx and GR levels in lycopene ingested diabetic patients.

Conclusion: Aforementioned observations suggested that oxidative stress increased in diabetics while ingestion of lycopene ( $4 \mathrm{mg} /$ day for 3 months) might alleviate oxidative stress in diabetic patients and warrants further investigations with large clinical trials.

Keywords: Diabetes; Oxidative stress; Lycopene; Malondialdehyde; Glutathione; Antioxidant enzymes

\section{Introduction}

Diabetes is a major worldwide health problem predisposing to markedly increased cardiovascular mortality and serious morbidity $[1,2]$. Due to altered dietary habits in both western and developing countries, the prevalence of Type 2 diabetes is growing at an exponential rate [3]. American Indians, African Americans, and Hispanics are about 2 times more likely than whites to have diabetes. One in three U.S. children born in 2000 could develop diabetes during their lifetime. Diabetes is the sixth leading cause of death. Over 200,000 people die each year of diabetes-related complications. In 2004, according to the World Health Organization (WHO), more than 150 million people worldwide suffered from diabetes. Its incidence is increasing rapidly. The WHO has predicted that the major burden will occur in developing countries. There will be a $42 \%$ increase from 52 to 72 million in developed countries and $170 \%$ increase from 84 to 228 million in the developing countries. In the year 2025, India, China and the United States of America (USA) will be the countries with the largest number of diabetic people [4]

In healthy subjects there is a balance between ROS formation and elimination. Every time this balance is lost due to an augmented production of reactive species or due to a reduction in antioxidant production or activity there is a condition of oxidative stress. Losing control of ROS is very harmful and almost all the constituents of the cell can be targets of these molecules. DNA, proteins, and lipids can be involved in chain reactions that entail their modification and, in the worst case, the loss of their functionality. Genetic degeneration and physiological dysfunction can lead to cell death and aging of the organism. On this basis it is not surprising that oxidative stress has been implicated in a growing list of human diseases with a leading place occupied by diabetes [5-7] for two reasons, the first being the epidemic proportions that this disease is assuming. Numbers are increasing: in 2003, people with diabetes numbered 197 million worldwide, rising to 333 million by 2025, with six million new cases every year [8], this means that every 10 seconds one person dies of diabetes-related diseases and in the same 10 seconds two people develop diabetes. The second reason is the unifying hypothesis that recent studies propose to explain the rise of diabetic complications, and that assign a leading role to oxidative stress [9]. Fighting diabetic complications will be the goal over the next few years.

Survey of literature revealed that diets rich in vegetables and fruits are associated with reduced risk of various diseases like cancers, coronary artery diseases, diabetes etc. Main role of these phytonutrients apart from providing fiber, indoles and phenols is found to be in reducing oxidative stress, as they contain natural nutrient antioxidants like carotenoids, flavanoids, vitamin C, vitamin A, vitamin E etc $[10,11]$ One of the novel phytonutrient antioxidants studied so far is lycopene.

*Corresponding author: Kuldip Singh, Department of Biochemistry, Government Medical College, Amritsar, Type-2B, Opposite Registrar Flats, Govt. Medical College Campus-Amritsar, Punjab, India, Tel: 09417355095; E-mail: drkuldip08@gmail.com

Received May 02, 2012; Accepted June 23, 2012; Published June 29, 2012

Citation: Singh K, Bal BS, Chopra S, Singh S, Malhotra N (2012) Ameliorative Effect of Lycopene on Lipid Peroxidation and Certain Antioxidant Enzymes in Diabetic Patients. J Diabetes Metab 3: 202. doi:10.4172/2155-6156.1000202

Copyright: (c) 2012 Singh K, et al. This is an open-access article distributed under the terms of the Creative Commons Attribution License, which permits unrestricted use, distribution, and reproduction in any medium, provided the original author and source are credited. 
Lycopene is an acyclic symmetric hydrocarbon, containing eleven conjugated and two unconjugated double bonds [12,13]. Because of its unique structure (high number of conjugated double bonds) lycopene indicates greater biological significance in human antioxidant defense system among the natural carotenoids [10]. It exists naturally in thermodynamically stable 'trans' form, so cooking especially with monosaturated fat like olive oil, makes it even more easily available for our body to utilize it. Information regarding the use and benefits of antioxidants in persons with diabetes is limited. So in the present study, we evaluated the effect of lycopene on oxidative stress biomarkers like MDA, and certain antioxidant enzymes such as XOD, SOD, GPx, GR and low molecular weight antioxidant compound GSH in diabetic patients.

\section{Material and Methods}

The study was conducted in the department of Biochemistry Govt. Medical College, Amritsar (Punjab- India) on 50 diabetic patients of both sexes in the age range of 35-55 years with raised glycosylated haemoglobin (HbAlc) attending O.P.D. and wards of the Medicine Department in Guru Nanak Dev Hospital, Amritsar. Equal number that is 50 of normal healthy subjects was selected from the general population as control. These subjects were divided into following three groups;

Group-1 ( $\mathrm{n}=50)$ : Normal healthy subjects (Control group)

Group-2 ( $\mathrm{n}=50)$ : NIDDM patients

Group-3 ( $\mathrm{n}=50)$ : NIDDM Patients+Lycopene (4 mg).

Diabetic patients, who suffered from the secondary causes of diabetes mellitus like cushing's syndrome, myxedema, acromegaly, thyrotoxicosis, pancreatitis or some genetic disorder were excluded from the study and patients with insulin dependent diabetes were also excluded. Also patients, who were already taking antioxidants or multivitamins, were also excluded from the study. Group-3 included those patients of NIDDM, who were administered $4 \mathrm{mg}$ of lycopene orally in capsule form once daily for 3 months. Dried powder of lycopene was procured (Jagson, Mumbai-India) and filled in capsules.

\section{Ethics}

The study protocol was approved by the institutional ethic committee. Study details \& potential risks and benefits were explained to the patients and written informed consent was obtained voluntarily from patients before entering into the study.

\section{Blood sampling}

Blood $(10 \mathrm{ml})$ samples were drawn from all the subjects following a fast of 12 hours with a dry disposable syringe and needle, under all aseptic conditions by venepuncture from the anticubital vein in sterile, dry and acid washed vial. The collected blood sample was divided in three sets of vials to assess the different biochemical assays as described below;

1. $2 \mathrm{ml}$ of the blood was collected into potassium oxalate and sodium fluoride mixture (1:3 ratio) containing vial and then centrifuged at $3000 \mathrm{rpm}$ for 15 minutes at $4^{\circ} \mathrm{C}$. The plasma obtained was used for the analysis of glucose.

2. $4 \mathrm{ml}$ of the blood sample was collected into heparinized vials and centrifuged at $3000 \mathrm{rpm}$ for 15 minutes at $4^{\circ} \mathrm{C}$ and the plasma obtained was used for the analysis of superoxide dismutase levels and heparinized whole blood sample was used for the estimation of $\mathrm{HbAlc}, \mathrm{GSH}$, GPx and GR.

3. $4 \mathrm{ml}$ of the blood was collected in acid washed sterile vials, this sample was allowed to clot \& then centrifuged at $3000 \mathrm{rpm}$ for $15 \mathrm{~min}-$ utes at $4^{\circ} \mathrm{C}$ and the serum obtained was used for the analysis of MDA and XOD levels.

\section{Biochemical assays}

Fasting glucose: Glucose was estimated based on glucose oxidase and peroxidase method as devised by Trinder, 1969 [14].

HbA1C: HbA1C was analyzed by applying the method of Susheela et al. [15].

MDA: MDA level in serum was assessed by the new colorimetric method of Satoh [16].

\section{Antioxidant initiating and scavenging enzymes}

1. XOD (EC 1.2.3.2): XOD levels in plasma were estimated by the method of Fried and Fried [17].

2. SOD (EC 1.5.1.1): SOD levels in plasma were estimated by the method of Kono [18].

3. GSH: GSH levels in blood were assessed using the method of Beutler et al.[19].

4. GPx (EC 1.11.1.7): GPx activity in whole blood was estimated by the method of Paglia and Valentine [20].

5. GR (EC 1.6.4.2): GR activity was estimated by applying the method of Glodberg and Spooner [21].

\section{Statistical analysis}

Results of biochemical analyses are presented as mean value \pm standard deviation (S.D.). The difference between control and test groups was analyzed by using Student " $t$ " test (significant difference at $\mathrm{p}<0.05$ confidence level). Correlation between the investigated groups was performed using test ONE-WAY ANOVA (one-way variance analysis).

\section{Results}

\section{MDA, XOD, SOD levels}

A significant increase $(\mathrm{P}<0.001)$ from $3.08 \pm 0.09 \mathrm{mmol} / \mathrm{ml}$ to 6.15 $\pm 0.04 \mathrm{mmol} / \mathrm{ml}$ by $99.60 \%$ in MDA levels and a significant increase $(\mathrm{P}<0.001)$ from $4.2 \pm 0.2 \mathrm{U} / \mathrm{L}$ to $10.10 \pm 1.1 \mathrm{U} / \mathrm{L}$ by $140.10 \%$ increase was observed in XOD (an antioxidants free radical initiating enzyme) levels was observed in diabetic patients with respect to (w.r.t) normal healthy control subjects (Figure 1). While a significant decrease by $25.85 \%$ (from $4.56 \pm 0.78 \mathrm{mmol} / \mathrm{ml}$ to $6.15 \pm 0.04 \mathrm{mmol} / \mathrm{ml}$ ) in MDA and $25.71 \%$ (from $10.12 .1 \mathrm{U} / \mathrm{L}$ to $8.51 \pm 2.10 \mathrm{U} / \mathrm{L}$ ) in XOD was found in lycopene ingested diabetic patients (Group-3) with respect to diabetic patients not receiving lycopene (Figure 1). SOD levels significantly $(\mathrm{P}<0.001)$ decreased from $3.94 \pm 0.36 \mathrm{U} / \mathrm{L}$ to $2.93 \pm 0.31 \mathrm{U} / \mathrm{L}$ in diabetic patients and a significant increase by $31.10 \%$ was recorded in SOD levels in lycopene ingested diabetic patients (Group-3) in comparison to diabetic patients not receiving lycopene (Figure 1).

\section{GSH, GPx and GR}

The results of GSH, GPx and GR are summarized in figure 2 and figure $2 \mathrm{~A}$ significant decrease $(\mathrm{P}<0.001)$ from $55.0 \pm 5.0 \mathrm{mg} / \mathrm{dL}$ to 36.00 $\pm 5.97 \mathrm{mg} / \mathrm{dL}$ (by $34.77 \%$ ) in GSH, $68.97 \pm 14.63 \mathrm{U} / \mathrm{L}$ to $34.34 \pm 11.28$ $\mathrm{U} / \mathrm{L}(\mathrm{P}<0.001$, by $50.21 \%)$ in GPx and $38.30 .20 \pm 10.11 \mathrm{U} / \mathrm{L}$ to $68.88 \pm$ $12.12 \mathrm{U} / \mathrm{L}$ (by $44.53 \%$ ) in GR levels was observed in diabetic patients (Figure 2). Whereas a significant increase by $31.60 \%$ (from $36.00 \pm 5.97$ $\mathrm{mg} / \mathrm{dL}$ to $47.00 \pm 5.93 \mathrm{mg} / \mathrm{dL}$ ), $30.64 \%$ (from $34.34 \pm 11.28 \mathrm{U} / \mathrm{L}$ to 44.86 


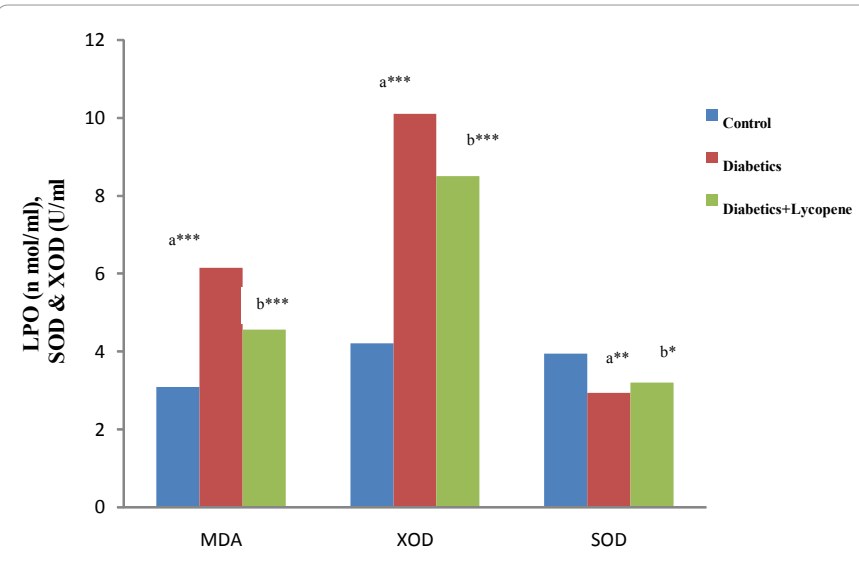

a. Represent the percent change with respect to controls (MDA $=+99.60, \mathrm{XOD}$ $=+140.10$ and SOD $=-25.63$ ).

b. Represent the percent change with respect to diabetics not receiving lycopene $(M D A=-25.85, X O D=-15.84$ and $S O D=+15.21)$.

${ }^{* * *} \mathrm{P}<0.001,{ }^{* *} \mathrm{P}<0.01$ and NS: Non significant

Figure 1: Changes in the levels of MDA, XOD and SOD in controls, diabetics and lycopene ingested diabetic patients. Values are expressed as mean $\pm \mathrm{SD}$.

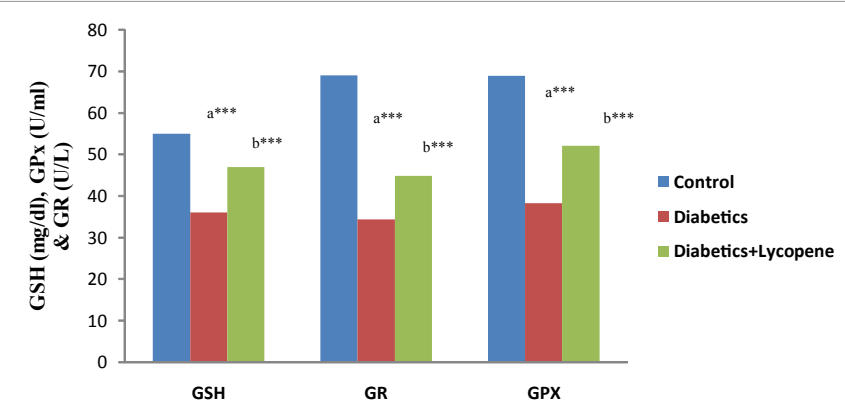

a. Represent the percent change with respect to controls (GSH $=-34.77, \mathrm{GPx}$ $=-50.21$ and $\mathrm{GR}=-44.53$ ).

b. Represent the percent change with respect to diabetics not receiving lycopene $(\mathrm{GSH}=+31.60, \mathrm{GPx}=+30.60$ and $\mathrm{GR}=-36.15)$.

${ }^{* * *} \mathrm{P}<0.001$

Figure 2: Changes in the levels of GSH, GPx and GR in controls, diabetics and lycopene ingested diabetic patients. Values are expressed as mean $\pm \mathrm{SD}$.

$\pm 7.93 \mathrm{U} / \mathrm{L}$ ) and $36.15 \%$ (from $52.12 \pm 13.00 \mathrm{U} / \mathrm{L}$ to $38.30 \pm 12.80 \mathrm{U} / \mathrm{L}$ ) in GSH, GR and GPx respectively was observed in lycopene ingested diabetic patients (Group-3) with respect to diabetic patients not receiving lycopene (Group-2) (Table 1 and Table 2).

\section{Discussion}

$\mathrm{XOD}$, a highly versatile enzyme that is widely distributed from bacteria to human, it exists predominantly as NAD+ dependent xanthine dehydrogenase $(\mathrm{XDH})$ that itself has no role in the initiation or potentiation of oxidative damage in cells. However, in many pathological conditions $\mathrm{XDH}$ is converted into XOD [22]. XOD, catalyses the oxidation of hypoxanthine/xanthine to uric acid and generates superoxide radical $\left(\mathrm{O}_{2}-\right)$. Hydrogen peroxide $\left(\mathrm{H}_{2} \mathrm{O}_{2}\right)$ formed from $\mathrm{O}_{2}$ - could be converted into highly reactive hydroxyl radical $(. \mathrm{OH})$ leading to oxidative stress as a result of oxidation of biological molecules. A significant increase $(\mathrm{P}<0.001$, Figure 1$)$ in XOD activity in diabetic patients could produce a burst of free radicals. Once $\mathrm{O}_{2}$ - radical produced then $\mathrm{H}_{2} \mathrm{O}_{2}$ and. $\mathrm{OH}$ are continuously produced by Haber-Weiss reaction and /or Fenton type reaction [23]. Oxygen radicals might cause the lipid peroxidation of biomembrane through a chain reaction. The first step is the initiation reaction, which begins by taking out hydrogen atom from polyunsaturated fatty acid (PUFA) by oxygen radical. The second is the propagation and the final step is termination. The extent of LPO has often been determined by the thiobarbituric acid (TBA) test, which has also been considered for the detection of malondialdehyde. In the present study, a significant $(\mathrm{P}<0.001)$ increase by $99.60 \%$ in MDA levels in diabetic patients with respect to control subjects (Figure 1) was observed, might lead to susceptibility of the biomembrane, which ultimately leads to tissue injury/damage.

SOD, a superoxide radical scavenging enzyme is considered the first line of defense against the deleterious effect of oxygen radicals in the cells and it scavenges reactive oxygen radical species by catalyzing the dismutation of $\mathrm{O}_{2}$ - radical to $\mathrm{H}_{2} \mathrm{O}_{2}$ and $\mathrm{O}_{2}$. In mammals, three isozymes of SOD that is CuZn-SOD, Mn-SOD and extra cellular-SOD exists [24]. CuZn-SOD is located primarily in the cytosol. CuZn-SOD consists of two protein sub units each has an active site containing one $\mathrm{Cu}$ ion and one $\mathrm{Zn}$ ion. $\mathrm{Cu}$ ion serves as active redox site and $\mathrm{Zn}$ ion maintain the protein structure. Mn-SOD is located in mitochondrial matrix [25]. It has four subunits each with Mn ion. EC-SOD is present in plasma, bound to heparin sulfate ion the surface of endothelial cells. EC-SOD is tetrameric glycoprotein, which contains $\mathrm{Cu}$ and $\mathrm{Zn}$ ion. The presence of SOD in various compartments of the our body enables it to dismutate $\mathrm{O}_{2}$ - radicals immediately and protects the cells from oxidative damage. A significant inhibition by $25.63 \%$ in SOD activity in diabetics (Figure 1) may results in an increased flux of $\mathrm{O}_{2}$ - radical and hence reflects the tissue damage/injury.

Glutathione (GSH), a tripeptide is maintained in reduced state by an efficient glutathione peroxidase/glutathione reductase system. Glutathione is a potent endogenous antioxidant that helps to protect cells from a number of noxious stimuli including oxygen derived free radicals [26,27]. A significant decrease in glutathione levels might be accompanied by a significant increase in LPO level. In the present work, the level of glutathione significantly decreased by $34.77 \%(\mathrm{p}<0.01)$ in diabetic patients (Group-2) with respect to control subjects (Figure 2). Reduced levels of GSH, confirm an increased susceptibility to oxidative damage and this observation is an agreement with the reports that inverse relationship exists between LPO and glutathione status. Glutathione depletion of $20 \%$ to $30 \%$ can impair the cell defense against the toxic action of xenobiotic and may lead to cell injury/death $[28,29]$.

The activity of GPx, a selenium-containing enzyme was found to be decreased by $50.21 \%(\mathrm{p}<0.001)$ in diabetics in comparison to control healthy subjects (Figure 1). GPx catalyses the reduction of variety of hydrogen peroxide $\left(\mathrm{ROOH}\right.$ and $\mathrm{H}_{2} \mathrm{O}_{2}$ ) using glutathione as a substrate, thereby protecting mammalian cells against oxidative stress [30]. It is well reported that low activity of this enzyme may render the tissue more susceptible to lipid peroxidation damage. Accordingly, in the present work, we observed a significant decrease in GPx activity upon increase in LPO level. This observation is in accordance with the hypothesis that LPO and GPx might play a role in tissue damage [3133]. The significant inhibition $(\mathrm{p}<0.001,44.53 \%)$ in the activity of GR in diabetics (Figure 2) attributed to increased oxidation or decreased synthesis of GSH. The less availability of NADPH may also cause a decrease in GR activity [34]. Our results of decreased levels of oxidative stress biomarkers (SOD, GPx, GR and GSH) and increased MDA \& $\mathrm{XOD}$ in the diabetic patients in comparison to normal healthy control subjects, indicates the increased oxidative stress in diabetes, causing the imbalance between oxidants and antioxidants, a key factor for diabetic complications. Our observations of attenuation of LPO, XOD, SOD, 


\begin{tabular}{|l|l|l|l|l|l|}
\hline S. No. & Subjects & \multicolumn{3}{|l|}{$\begin{array}{l}\text { Total number of subjects and their } \\
\text { sex distribution }\end{array}$} & $\begin{array}{l}\text { Mean age } \\
\text { (years) }\end{array}$ \\
\cline { 3 - 5 } & Total & Males & Females & \\
\hline 1 & Controls & 50 & 22 & 28 & $44.60 \pm 5.10$ \\
\hline 2 & Patients & 50 & 23 & 27 & $48.10 \pm 6.00$ \\
\hline 3 & Patients+Lycopene & 50 & 23 & 27 & $48.10 \pm 6.00$ \\
\hline
\end{tabular}

Table 1: Demographic profile of the subjects (controls as well as the patients of Type-2 Diabetes Mellitus) under study.

\begin{tabular}{|l|c|c|c|}
\hline Biochemical Analysis & $\begin{array}{c}\text { Group-1 } \\
\text { (Control) }\end{array}$ & $\begin{array}{c}\text { Group-2 } \\
\text { (Diabetic Patients) }\end{array}$ & $\begin{array}{c}\text { Group-3 } \\
\text { (Diabetics } \\
\text { Patients+Lycopene) }\end{array}$ \\
\hline FBS $(\mathrm{mg} / \mathrm{dl})$ & $90.53 \pm 8.00^{\mathrm{a}}$ & $\begin{array}{c}167.22 \pm 28.4 \\
(84.71)^{\mathrm{b} * * *}\end{array}$ & $\begin{array}{c}151.86 \pm 15.7 \\
(-9.18)^{\mathrm{c}}\end{array}$ \\
\hline $\mathrm{HbA1C}(\% \mathrm{Hb})$ & $5.82 \pm 1.23$ & $9.22 \pm 1.16$ & $\begin{array}{c}8.64 \pm 1.88 \\
(+41.23)^{\mathrm{b} * *}\end{array}$ \\
& & & $(-7.05)^{\mathrm{c}}$ \\
\hline
\end{tabular}

${ }^{a}$ values are Mean \pm S.D. of 50 observations

bValues in parentheses represent percentage change with respect to control

'Values in parentheses represent percentage change with respect to diabetic patients ${ }^{* * *} p<0.001$

Table 2: Changes in fasting blood sugar and glycosylated haemoglobin in norma healthy volunteers, patients of Type- 2 Diabetes Mellitus and lycopene ingested diabetic patients.

GSH, GPx and GR levels in diabetic patients are in agreement with the literature reports $[3,34]$ that oxidative stress is induced in diabetes.

Recently, studies have shown the beneficial effect of tomato product (rich sources of lycopene) or other carotenoid rich vegetable (Spinach, carrot) consumption in reducing oxidative stress in adults [35-37]. Lycopene, a potent antioxidant and having very good free radical scavenging capacity because of its unique structure (high number of conjugated double bonds), might have quenched the superoxide and other free radical anions, which are highly released in chronic diseases like cancer and coronary heart diseases, diabetes etc. $[10,38,39]$ is thought to have great biological significance in human antioxidant defense system.

A significant reduction in $\mathrm{MDA}(25.85 \%, \mathrm{p}<0.01)$ and $\mathrm{XOD}$ $(25.71 \%, \mathrm{p}<0.01)$ levels (Figure 3$)$ was observed upon ingestion of lycopene $(4 \mathrm{mg} /$ day) to diabetic patients for 3 months, indicating that lycopene acting as a chain breaking antioxidant. Lycopene reacts with peroxyl radicals formed in the propagation phage of lipid peroxidation to form carbon centred radicals. These carbon centred radicals then react readily and reversibly with oxygen to form new chain carrying peroxyl radicals which are stable than reactive oxygen species. In addition, a significant increase in the levels of most important cytosolic enzymes like SOD, GPx \& GR and low molecular weight compound i.e., GSH was found in lycopene ingested diabetic patients with respect to diabetic patient not receiving lycopene (Figure 1 and 2), resulting in alleviation of oxidative stress in diabetics.

In conclusion, aforementioned observations suggested that oxidative stress increased in diabetics whereas lycopene have an effective antioxidant property for improving the consequences of oxidants: antioxidants imbalance and warrants further investigations with large clinical trials.

\section{References}

1. Hur J, Sullivan KA, Schuyler AD, Hong Y, Pande M, et al. (2010) Literaturebased discovery of diabetes- and ROS-related targets. BMC Med Genomics 3: 49 .

2. Tsutsui H, Kinugawa S, Matsushima S, Yokota T (2011) Oxidative stress in cardiac and skeletal muscle dysfunction associated with diabetes mellitus. $J$. Clin. Biochem. Nutr 48: 68-71.

3. Faffly JRP (2001) Review on Diabetic complications. Free Rad Biol \& Med 77 222-237.

4. King H, Aubert RE, Herman WH (1998) Global Burden of Diabetes, 1995-2025 Prevalence, numerical estimates, and projections. Diabetes Care 21: 14141431.

5. Johansen JS, Harris AK, Rychly DJ, Ergul A (2005) Oxidative stress and the use of antioxidants in diabetes: linking basic science to clinical practice. Cardiovasc Diabetol 4: 5.

6. Maritim AC, Sanders RA, Watkins JB $3^{\text {rd }}$ (2003) Diabetes, Oxidative Stress, and Antioxidants: A Review. J Biochem Mol Toxicol 17: 24-38.

7. Evans JL, Goldfine ID, Maddux BA, Grodsky GM (2002) Oxidative stress and stress-activated signaling pathways: a unifying hypothesis of type 2 diabetes. Endocr Rev 23: 599-622.

8. Wild S, Roglic G, Green A, Sicree R, King H (2004) Global prevalence of diabetes: estimates for the year 2000 and projections for 2030. Diabetes Care 27 1047-1053.

9. Brownlee M (2005) The pathobiology of diabetic complications: a unifying mechanism. Diabetes 54: 1615-1625.

10. Rao AV, Agrawal S (1999) Role of lycopene as antioxidant carotenoid in the prevention of chronic diseases, a review. Nutrition Research 19: 305-323.

11. Ali MM, Agha FG (2009) Ameliorattion of streptozotocin-induced diabetes mellitus, oxidative stress and dyslipidemia in ratsby tomato extract lycopene. Scan J Clin Lab Invest 69: 371-379.

12. Devaraj S, Mathur S, Basu A, Anug HH, Vasu VT, et al. (2008) A dose response study on the effects of purified lycopene supplementation on biomarkers of oxidative stress. J Am Coll Nutr 27: 267-273.

13. Nguyen ML, Schwartz SJ (1999) Lycopene: chemical and biological properties. Food Technol 53: 38-45.

14. Trinder P (1969) Enzymatic method of glucose estimation. Ann Clin Biochem 6: 24-33.

15. Susheela L, Ramachandran A, Mohan V, Viswanathan MA (1986) A semi-micro colorimetric method for estimating glycosylated haemoglobin. Indian $\mathrm{J}$ Med Res 84: 93-98.

16. Satoh K (1978) Serum lipid peroxide in cerebrovascular disorders determined by a new colorimetric method. Clin Chim Acta 90: 37-43.

17. Fried R, Fried LW (1974) Xanthine oxidase (Xanthine dehydrogenase), method of enzymatic analysis. Ed. Bergmeyer HU. Academic Press NY, London 2: 644 659 .

18. Kono Y (1978) Generation of superoxide radical during autoxidation of hydroxylamine and an assay for superoxide dismutase. Arch Biochem Biophys 186: 189-195.

19. Beutler E, Duron O, Kelly BM (1963) Improved method for the determination of blood glutathione. J Lab Clin Med 61: 882-888

20. Paglia DE, Valentine WN (1967) Estimation of plasma glutathione peroxidase J Lab Clin Med 70: 158-169.

21. Glodberg DM, Spooner RJ (1983) Glutathione reductase. In: Bergmeyer HU (eds). Methods of Enzymatic Analysis. Deerfield Beach, FI: Verlag Chemie 3 258-265.

22. Xu P, Huecksteadt TP, Harrison R, Hoidal JR (1994) Molecular cloning, tissue expression of human xanthine dehydrogenase. Biochem Biophy Res Commum 199: 998-1004.

23. Gil P, Fariñas F, Casado A, López-Fernández E (2002) Malondialdehyde: a possible marker of ageing. Gerontology 48: 209-214.

24. Marklund SL (1984) Properties of extra cellular superoxide dismutase form human lung. Biochem J 220: 269-272.

25. Bast A, Haenen GR (1984) Cytochrome P450 and glutathione: what is the Significance of their interrelationship in lipid peroxidation? Trends Bio Sci 9: 510-513.

26. Kim BJ, Hood BL, Aragon RA, Hardwick JP, Conrads TP, et al. (2006) Increased 
Citation: Singh K, Bal BS, Chopra S, Singh S, Malhotra N (2012) Ameliorative Effect of Lycopene on Lipid Peroxidation and Certain Antioxidant Enzymes in Diabetic Patients. J Diabetes Metab 3: 202. doi:10.4172/2155-6156.1000202

Page 5 of 5

oxidation and degradation of cytosolic proteins in alcohol-exposed mouse liver and hepatoma cells. Proteomics 6: 1250-1260.

27. Onyema OO, Farombi EO, Emerole GO, Ukoha Al, Onyeze GO (2006) Effect of vitamin $\mathrm{E}$ on monosodium glutamate induced hepatotoxicity and oxidative stress in rats. Indian J Biochem Biophys 43: 20-24.

28. Padmini E, Sundari BT (2008) Erythrocyte Glutathione depletion impairs resistance to haemolysis in women consuming alcohol. J Clin Biochem Nutr 42: 14-20.

29. Chaudhary P, Malik VBT, Puri S, Ahluwalia P ( 1996) Studies on the effect of monosodium glutamate on hepatic microsomal lipid peroxidation, calcium, ascorbic acid and glutathione and its dependent enzymes in adult male mice. Toxicol Lett 9: 71-76.

30. Nakazawa H, Genka C, Fujishima M (1996) Pathological aspects of active oxygens/ free radicals. Jpn J Physiol 46: 15-32.

31. Blum J, Fridovich I (1985) Inactivation of glutathione peroxidase by superoxide radical. Arch Biochem Biophys 240: 500-508.

32. Raes M, Mihiels MC, Remacle J (1987) Comparative study of the enzymatic defense systems against oxygen derived free radicals: the key role of glutathione peroxidase. Free Radic Biol Med 3: 3-7.

33. Lapennna D, de Gioia S, Ciotani G, Mezzetti A, Ucchino S, et al. (1998) Gluta- thione related antioxidant defenses in human atherosclerotic plaques. Circulation 97: 1930-1934.

34. Gul M, Kutay FZ, Temocin S, Hanninen O (2000) Cellular and clinical implications of glutathione. Ind J Exp Biol 38: 625-634.

35. Rao AV (2002) Lycopene, tomatoes, and the prevention of coronary heart diseases. Exp Biol Med (Maywood) 227: 908-913

36. Neyestani TR, Shariatzadeh N, Gharavi A, Kalayi A, Khalaji N (2007) Physiological dose of lycopene suppressed oxidative stress and enhanced serum levels of immunoglobulin $\mathrm{M}$ in patients with Type 2 diabetes mellitus: a possible role in the prevention of long-term complications. J Endocrinol Invest 30: 833-838.

37. Saveeta A, Kuldip S, Nagpal M, Kaur A, Ahluwalia P (2009) Studies on the ef fect of lycored supplementation (Lycopene) on lipid peroxidation and reduced glutathione in pregnanacy induced hypertensive patients. Biomed Res 20: 51 54

38. Khachik F, Carvalho L, Bernstein PS, Muir GJ, Zhao DY, et al. (2002) Chem istry, distribution, and metabolism of tomato carotenoids and their impact on human health. Exp Biol Med (Maywood) 227: 845-851.

39. Upritchard JE, Sutherland WH, Mann JI (2000) Effect of supplementation with tomato juice, vitamin $E$ and $C$ on LDL oxidation and products of inflammatory activity in type-2 diabetes. Diabetes Care 23: 733-738. 